\title{
STUDI KEANEKARAGAMAN DIATOM EPILITIK SERTA POTENSINYA SEBAGAI BIOINDIKATOR KUALITAS PERAIRAN SUNGAI DI COBAN TARZAN KABUPATEN MALANG
}

\section{EPILITHIC DIATOM DIVERSITY STUDY AND ITS POTENTIAL AS BIOINDICATOR OF RIVER WATERS QUALITY IN COBAN TARZAN MALANG REGENCY}

\author{
Bayu Agung Prahardika ${ }^{1)^{*}}$, Widi Muhammad Lutsfi Dwi Styawan')
}

\author{
Diterima : 28 Mei 2020 \\ Disetujui : 20 Agustus 2020
}

\begin{tabular}{l}
\hline Afiliasi Penulis: \\
1) Program Studi Biologi, Fakultas \\
Sains dan Teknologi, UIN \\
Maulana Malik Ibrahim, Malang, \\
Indonesia \\
\hline Alamat Korespondensi: \\
* bayu.agung.prahardika@ gmail.com
\end{tabular}

\begin{tabular}{lrr}
\hline Cara Sitasi: & & \\
Prahardika, & B.A., & W.M.L.D. \\
Styawan. & 2020. & Studi \\
keanekaragaman diatom & epilitik \\
serta potensinya & sebagai \\
bioindikator & kualitas & perairan \\
sungai di & Coban & Tarzan \\
Kabupaten Malang: & Journal of \\
Tropical Biology 8(2): & $116-124$ \\
\hline
\end{tabular}

\begin{abstract}
ABSTRAK
Air selalu menjadi kebutuhan penting dalam memenuhi segala aspek kehidupan bagi semua makhluk hidup. Keberadaan sumber daya perairan harus didukung dengan kuantitas yang tercukupi serta kualitas yang baik. Salah satu sumber daya perairan yang sering dimanfaatkan oleh makhluk hidup adalah sungai, terutama aliran sungai yang berasal dari air terjun (coban). Tujuan penelitian ini untuk mengetahui keanekaragaman jenis diatom epilitik serta potensinya sebagai organisme indikator penentu kualitas perairan sungai di Coban Tarzan Kabupaten Malang. Pengambilan sampel diatom epilitik dilakukan dengan metode terpilih (purposive sampling) pada tiga stasiun di perairan sungai Coban Tarzan. Sampel diatom epilitik diambil dari substrat batuan yang terendam air dan tidak lebih dari kedalaman $20 \mathrm{~cm}$. Parameter yang diamati dan diukur antara lain Kepadatan (K), Indeks Keanekaragaman Shannon Wiener (H'), Indeks Dominansi Simpson $(C)$ dan Indeks Tropik Diatom Epilitik. Hasil pengamatan menunjukkan bahwa kepadatan total diatom epilitik yang ditemukan di Coban Tarzan selama penelitian adalah $152.669 \mathrm{ind} / \mathrm{cm}^{2}$, yang terdiri delapan genus (Amphora, Cocconeis, Cymbella, Fragilaria, Gomphonema, Navicula, Nitzschia dan Rhoicosphenia). Sementara itu nilai $H^{\prime}$ diatom epilitik di sungai Coban Tarzan menunjukkan tingkat keanekaragaman yang sedang $\left(H^{\prime}=1,52\right)$, sedangkan untuk nilai $C$ menunjukkan tidak ada spesies diatom epilitik yang mendominasi di perairan tersebut $(C=0,25)$. Hasil indeks tropik diatom epilitik menunjukkan perairan sungai Coban Tarzan tergolong memiliki kualitas perairan dengan kategori sedang (mesotrofik).
\end{abstract}

Kata kunci: bioindikator, coban tarzan, diatom epilitik, sungai

ABSTRACT
Water has always been an essential requirement in meeting all aspects of life for all living things. Sufficient quantities and good quality must support the existence of water resources. One of the water resources that is often utilized by living things is rivers, especially streams that originate from waterfalls (coban). The purpose of this study was to determine the species diversity of epilithic diatom and its potential as an indicator organism that determines river water quality in Coban Tarzan Malang Regency. The sampling of epilithic diatoms was carried out by the selected method (purposive sampling) at three stations in the waters of the Coban Tarzan river. Epilithic diatom samples taken from rock substrate submerged in water and no more than $20 \mathrm{~cm}$ deep. Parameters observed and measured include Density $(K)$, Shannon Wiener Diversity Index $\left(H^{\prime}\right)$, Simpson Dominance Index $(C)$ and Diatom Tropic Index. The observations showed that the total density of epilithic diatoms found in Coban Tarzan was 152,669 ind/ $\mathrm{cm}^{2}$, consisting of eight genera (Amphora, Cocconeis, Cymbella, Fragilaria, Gomphonema, Navicula, Nitzschia and Rhoicosphenia). Meanwhile, the H'value of epilithic diatoms in the Coban Tarzan river shows a moderate level of diversity $\left(H^{\prime}=1.52\right)$, while for the $C$ value, there are no epilithic diatom species that dominate in these waters $(C=$ 
0.25). The epilithic diatom tropic index results show that the Coban Tarzan river waters are classified as having medium quality waters (mesotrophic).

Keywords: bioindicator, Coban Tarzan, epilithic diatom, river

\section{PENDAHULUAN}

Air menjadi salah satu sumber daya alam yang dibutuhkan oleh semua makhluk hidup. Keberadaan air selalu menjadi kebutuhan penting dalam memenuhi segala aspek kehidupan. Kebutuhan air yang semakin meningkat harus didukung oleh kuantitas sumber daya air yang tercukupi serta didukung oleh kualitas yang baik [1]. Salah satu sumber daya perairan yang banyak dimanfaatkan oleh makhluk hidup adalah sungai.

Malang sebagai salah satu kabupaten di Jawa Timur dengan daya tarik pariwisatanya yang sangat menarik untuk terus dijelajahi. Salah satu obyek wisata yang menjadi daya tarik utama di Kabupaten Malang adalah keberadaan air terjun (atau dalam bahasa Jawa disebut sebagai coban). Coban Tarzan menjadi salah satu contoh obyek wisata air terjun baru di Kabupaten Malang. Coban ini berada Kecamatan Jabung yaitu di sekitar kaki Gunung Bromo [2].

Keberadaan perkebunan masyarakat serta peningkatan jumlah pengunjung dan aktivitas pariwisata yang semakin berkembang, khususnya di sekitar aliran Coban Tarzan, dikhawatirkan dapat berpengaruh terhadap kualitas perairannya. Sebab aliran air dari coban tersebut juga menjadi aliran sungai bagi daerah sekitarnya. Menurut [3], sungai merupakan jenis perairan mengalir (lotik) dan terbuka, sehingga rawan tercemar oleh limbah pertanian, pemukiman, serta aktivitas industri termasuk juga aktivitas pariwisata.

Peningkatan aktivitas antropogenik (perkebunan dan pariwisata) di sekitar aliran sungai Coban Tarzan dikhawatirkan akan dapat menyebabkan perubahan kualitas perairannya. Sebagai organisme yang relatif menetap, keberadaan diatom epilitik dapat digunakan sebagai salah satu alternatif organisme/biota perairan untuk menggambarkan kondisi habitat perairan tersebut. Diatom epilitik adalah komunitas mikroalga yang kelangsungan hidupnya adalah menempel pada substrat bebatuan yang terdapat di ekosistem perairan
[4]. Menurut [5], diatom memiliki respon yang variatif terhadap kondisi kualitas perairan mulai dari yang sensitif hingga toleran. Respon yang ditunjukkan diatom terhadap kualitas perairan menurut [6] yaitu berupa kelimpahan, jumlah jenis dan kolonisasi taksa. Diatom dapat digunakan untuk mengkaji, menilai, dan memantau kondisi perairan sungai. Hal tersebut karena persebaran diatom yang kosmopolit di seluruh dunia, sehingga penerapannya dapat digunakan di seluruh dunia [7].

Perubahan kualitas air dan subtrat tempat hidup dari diatom epilitik akan sangat memengaruhi komposisi dan kelimpahan komunitasnya. Kandungan nutrien di perairan sangat berhubungan dengan kepadatan plankton atau diatom yang terdapat di dalamnya, semakin tinggi kandungan nutrien di suatu perairan maka semakin tinggi juga kepadatannya, sehingga tinggi rendahnya kepadatan tersebut juga dapat digunakan sebagai indikator kualitas hayati [8]. Oleh karena itu, dalam penelitian ini akan dilakukan penentuan kualitas perairan Coban Tarzan dengan menggunakan pendekatan kepadatan, keanekaragaman jenis dan dominansi diatom epilitik serta status kualitas air menurut Indeks Tropik Diatom (TDI). Penelitian ini nantinya diharapkan dapat digunakan sebagai studi awal kondisi perairan Coban Tarzan yang baru terpapar oleh aktivitas masyarakat sekitar (perkebunan dan pariwisata).

\section{METODE PENELITIAN}

Waktu dan tempat penelitian. Penelitian ini dilaksanakan pada bulan September Oktober 2019. Pengambilan sampel diatom epilitik dilakukan di aliran sungai Coban Tarzan (Gambar 1). Sementara itu, identifikasi, analisis indeks diversitas, indeks dominansi, dan indeks tropik diatom epilitik dilakukan di Laboratorium Ekologi dan Laboratorium Optik Jurusan Biologi Fakultas Sains dan Teknologi Universitas Islam Negeri Maulana Malik Ibrahim Malang. 


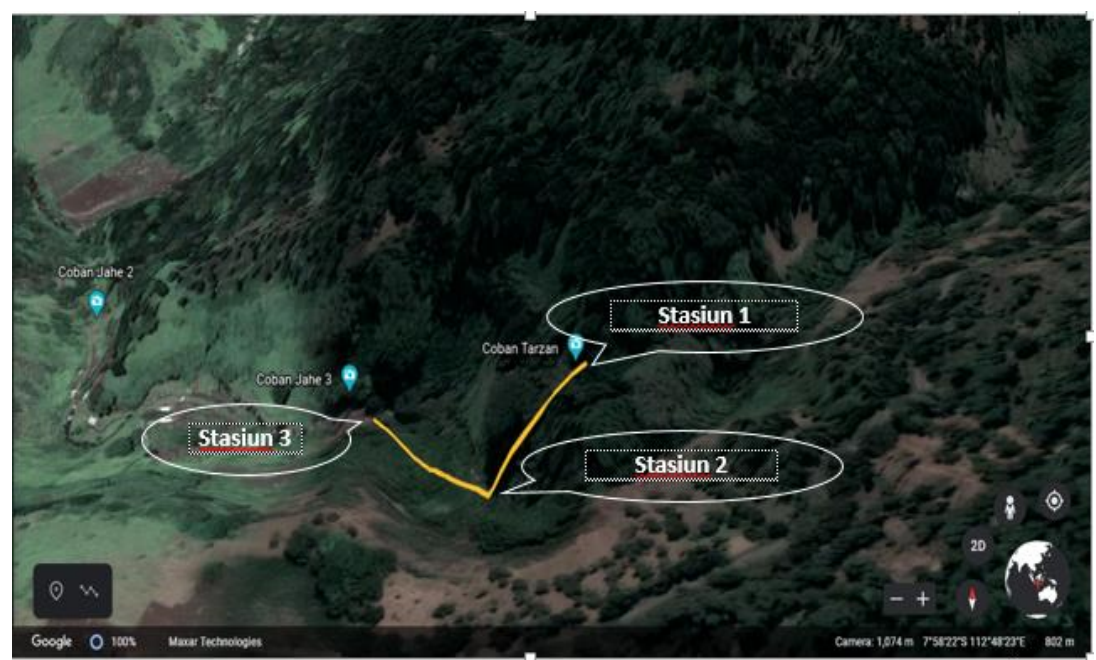

Gambar 1. Peta lokasi pengambilan sampel diatom epilitik (Google Earth, 2019)

Metode penelitian. Metode yang digunakan dalam penelitian ini yaitu metode eksplorasi. Secara teknis yaitu dengan pengambilan sampel diatom epilitik langsung dari lokasi penelitian kemudian sampel diatom epilitik tersebut diamati dan diidentifikasi di laboratorium.

Pengambilan sampel diatom epilitik dilakukan dengan metode terpilih (purposive sampling) pada tiga stasiun di perairan sungai Coban Tarzan, jarak setiap stasiun pengamatan adalah sekitar $300 \mathrm{~m}$ (sesuai dengan karakteristik perbedaan aktivitas masyarakat di sekitarnya). Stasiun satu merupakan daerah/titik awal jatuhnya aliran air terjun di Coban Tarzan, stasiun dua merupakan aliran Coban Tarzan dengan daerah sekitar didominasi oleh perkebunan sayuran milik masyarakat setempat, sedangkan stasiun tiga adalah daerah sekitar pusat aktivitas wisata dengan dominasi adanya cafe di sekitarnya. Kemudian, pada setiap stasiun diambil tiga titik sub stasiun, dengan jarak 5 meter antara sub stasiun 1 sampai 3 [9]. Sampel diatom epilitik diambil pada pagi hari dari substrat batuan yang terendam air tetapi masih terpapar sinar matahari, serta tidak lebih dari kedalaman 20 $\mathrm{cm}$ [10]. Batuan yang berlumpur dan batuan yang terdapat alga berfilamen atau terdapat tumbuhan dihindari untuk mencegah masuknya genus taksa dari diatom epipelik dan epifit ke dalam sampel [9].

Sampel diatom epilitik diambil dari permukaan substrat batu yang disikat dengan menggunakan sikat gigi, luasan batu yang disikat mengacu pada literatur dari [11], [12] dan [13] yaitu berukuran $100 \mathrm{~cm}^{2}$. Batu yang terpilih untuk disikat selanjutnya dibilas/dicuci dengan akuades kemudian dimasukkan ke dalam botol sampel hingga dengan volume yang tepat $20 \mathrm{ml}$. Sampel kemudian diawetkan dengan menggunakan larutan lugol 1\%, selanjutnya sampel disimpan di coolbox, dengan pendinginan pada suhu $4{ }^{\circ} \mathrm{C}$, pengawetan dengan lugol iodin mengacu pada [9] dan [14]. Pengawetan dengan lugol juga disarankan untuk perhitungan sampel diatom, karena lugol iodin dapat menghambat sampel yang bergerak pada saat pengamatan dan bergerak masuk ruang perhitungan yang lain sehingga menyebabkan hasil tidak akurat [15]. Langkah selanjutnya dianalisis di laboratorium untuk dilakukan pengamatan dan identifikasi sampel diatom epilitik yang ditemukan. Identifikasi diatom epilitik yang dilakukan yaitu berdasarkan morfologi dari frustul, sesuai dengan literatur dari [16]. Selain itu, identifikasi juga berdasarkan keberadaan raphe, bentuk valve, apices dan striea [17]. Taksa diatom diidentifikasi dengan menggunakan buku identifikasi mikroalga dan diatom [17], [18] dan [19].

Analisis data. Analisis data terhadap diatom epilitik yang dilakukan meliputi Kepadatan (K), Indeks Keanekaragaman Shannon Wiener ( $\left.\mathrm{H}^{\prime}\right)$, Indeks Dominansi Simpson (C) serta Indeks Tropik Diatom. Nilai kepadatan diatom epilitik dapat ditentukan dengan rumus sebagai berikut [20]:

$$
\mathrm{K}=\frac{\mathrm{C} \times \mathrm{At}}{\operatorname{As} \times \mathrm{S} \times \mathrm{V}}
$$

Keterangan:

$\mathrm{K}:$ Kepadatan (ind $/ \mathrm{cm}^{2}$ )

$\mathrm{C}$ : Jumlah individu diatom i yang dihitung pada kotak contoh pengamatan $(1,2,3,4$ dan 5)

At : Luas area slip penutup $\left(0.01 \mathrm{~cm}^{2}\right)$

As : Luas area bidang/sampel batu $\left(100 \mathrm{~cm}^{2}\right)$

S : Jumlah bidang/kotak yang dihitung (25)

$\mathrm{V}$ : Volume sampel di bawah slip penutup $(0,0001 \mathrm{~mL})$ 
Indeks keanekaragaman Shannon

Wiener (H'). Keanekaragaman jenis diatom epilitik dapat diketahui melalui Indeks Keanekaragaman Shannon Wiener [21]:

$$
\mathrm{H}^{\prime}=-\sum \mathrm{Pi} \ln \mathrm{Pi}
$$

Keterangan:

H': Indeks Keanekaragaman Shannon Wiener

$\mathrm{Pi}:$ ni/N

ni : Jumlah individu jenis ke-i

$\mathrm{N}$ : Jumlah total individu

Dengan:

$\mathrm{H}^{\prime}<1$ : Keanekaragaman spesies rendah

$1<H^{\prime}<3$ : Keanekaragaman spesies sedang

$\mathrm{H}^{\prime}>3$ : Keanekaragaman spesies tinggi

Indeks dominansi Simpson. Analisis indeks dominansi dilakukan untuk mengetahui keberadaan jenis organisme yang mendominasi dalam suatu komunitas dibandingkan dengan jenis lainnya. Indeks dominansi dapat diketahui melalui Indeks Dominansi Simpson dengan rumus [22]:

$$
\mathrm{C}=\sum(\mathrm{ni} / \mathrm{N})^{2}
$$

Keterangan:

C : Indeks dominansi Simpson

ni : Jumlah individu jenis ke-i

$\mathrm{N}$ : Jumlah total individu

Dengan:

Nilai indeks dominansi (C) yaitu antara 0-1, apabila lebih dekat ke 0 maka tidak ada dominansi suatu spesies terhadap spesies lainya dan kondisi struktur komunitas stabil. Sedangkan, apabila nilai indeks dominansi mendekati 1 maka terdapat spesies yang mendominansi spesies yang lain, sehingga struktur komunitas labil serta terjadi tekanan ekologis.

Indeks Tropik Diatom. Penentuan nilai Indeks Tropik Diatom (Trophic Diatoms Index, TDI) digunakan untuk menentukan status trofik perairan coban. Perhitungan indeks tropik diatom membutuhkan data kelimpahan dan komposisi taksa diatom, selain itu juga membutuhkan data toleransi dari taksa diatom di perairan. Perhitungan TDI didasarkan pada keberadaan diatom. Setiap diatom memiliki nilai sensivitas (s) serta nilai indikator (v) masing-masing yang terdapat dalam [23] dan [24]. Rumus dari TDI adalah:
$\mathrm{TDI}=(\mathrm{WMS} \times 25)-25$

$$
\mathrm{WMS}=\frac{\sum \text { aj. vj. sj }}{\sum \text { aj.vj }}
$$

Keterangan:

WMS : Weighted Mean Sensitivity (rata-rata bobot taksa sensitif yang ditemukan)

aj : Kelimpahan diatom-j yang ditemukan pada sampel

sj : Nilai sensitivitas diatom-j terhadap pencemaran bahan organik

vj : Nilai indikator taksa-j

Dengan kategori nilai dan status pencemaran TDI adalah:

$$
\begin{aligned}
& 0-35: \text { tidak tercemar } \\
& 35-50: \text { tercemar rendah } \\
& 50-60: \text { tercemar sedang } \\
& 60-75: \text { tercemar tinggi } \\
& 75-100: \text { tercemar sangat tingg }
\end{aligned}
$$

\section{HASIL DAN PEMBAHASAN}

Komposisi diatom epilitik. Diatom epilitik yang ditemukan di aliran sungai Coban Tarzan, Kabupaten Malang adalah sebanyak delapan genus yang termasuk ke dalam delapan famili, enam ordo dan dua kelas (Tabel 1). Genus diatom epilitik yang sering ditemukan pada setiap stasiun adalah Coconneis, Gomphonema, Navicula dan Rhoicospenia. Genus diatom epilitik jarang ditemukan adalah Amphora dan Cymbella. Setiap stasiun memiliki komposisi genus yang berbeda-beda. Menurut [25], diatom memiliki toleransi yang berbeda-beda terhadap kualitas air tempat hidupnya. Sehingga setiap jenis diatom epilitik memiliki perbedaan dalam merespon kondisi lingkungan tempat hidupnya, seperti misalnya ada jenis yang sensitif maupun yang toleran. Foto hasil pengamatan diatom epilitik yang ditemukan di aliran sungai Coban Tarzan terdapat pada Tabel 2.

Setiap stasiun pengamatan memiliki komposisi genus diatom epilitik yang berbedabeda. Menurut [26] menyatakan bahwa diatom dalam merespon kondisi lingkungan tempat hidupnya cukup bervariasi, ada jenis yang sensitif dan toleran. Salah satu jenis diatom yang memiliki toleransi tinggi terhadap kondisi perairan adalah Nitzschia dan Navicula yang ditemukan di hampir seluruh stasiun pengamatan di Sungai Cileungsi [26]. 
Tabel 1. Jenis diatom epilitik yang ditemukan di Coban Tarzan, Kabupaten Malang

\begin{tabular}{clll}
\hline Kelas & \multicolumn{1}{c}{ Ordo } & \multicolumn{1}{c}{ Famili } & \multicolumn{1}{c}{ Genus } \\
\hline Bacillariophyceae & Achnanthales & Cocconeidaceae & Cocconeis \\
& Bacillariales & Bacillariaceae & Nitzschia \\
& Cymbellales & Cymbellaceae & Cymbella \\
& & Gomphonemataceae & Gomphonema \\
& & Rhoicospheniaceae & Rhoicosphenia \\
& Naviculales & Naviculaceae & Navicula \\
& Thalassiophysales & Catenulaceae & Amphora \\
Fragilariophyceae & Fragilariales & Fragilariaceae & Fragilaria \\
\hline
\end{tabular}

Tabel 2. Diatom epilitik di Coban Tarzan, Kabupaten Malang

\begin{tabular}{|c|c|c|}
\hline No & Nama & Foto Hasil Pengamatan (Perbesaran 1000x) \\
\hline 1 & Amphora & \\
\hline 2 & Cocconeis & \\
\hline 3 & Cymbella & \\
\hline 4 & Fragilaria & \\
\hline 5 & Gomphonema & \\
\hline 6 & Navicula & \\
\hline 7 & Nitzschia & \\
\hline 8 & Rhoicospenia & \\
\hline
\end{tabular}


Kepadatan diatom epilitik. Kepadatan total diatom epilitik yang ditemukan di Coban Tarzan adalah $152.669 \mathrm{ind} / \mathrm{cm}^{2}$ (Gambar 2). Nilai rata-rata kepadatan diatom epilitik setiap stasiun adalah stasiun satu dengan 20.556 ind $/ \mathrm{cm}^{2}$, stasiun dua dengan $16.556 \mathrm{ind} / \mathrm{cm}^{2}$, sedangkan di stasiun tiga dengan 13.778 ind $/ \mathrm{cm}^{2}$. Nilai kepadatan tertinggi yaitu di stasiun satu sedangkan yang paling rendah adalah di stasiun tiga.

\section{Kepadatan Total Diatom Epilitik}

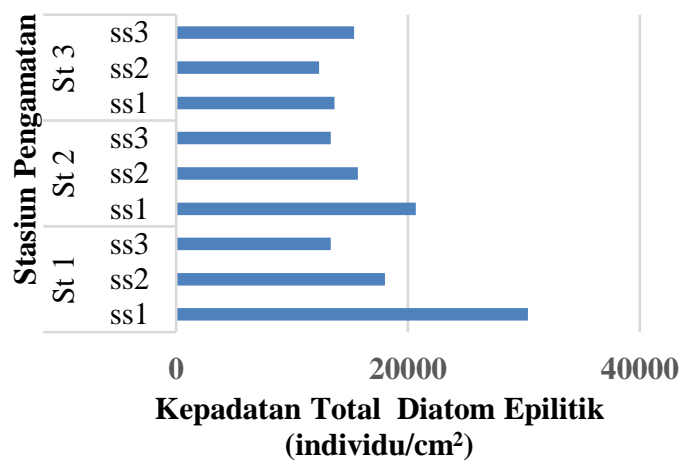

Gambar 2. Kepadatan total diatom epilitik di Coban Tarzan

Kepadatan setiap genus menunjukkan perbedaan nilai. Genus dengan kepadatan yang cukup tinggi di Coban Tarzan adalah Cocconeis, Gomphonema dan Rhoicospenia. Nilai kepadatan tertinggi adalah genus Rhoicospenia dengan $45.000 \mathrm{ind} / \mathrm{cm}^{2}$, sedangkan yang paling rendah adalah Amphora dengan $1000 \mathrm{ind} / \mathrm{cm}^{2}$ (Gambar 3). Beberapa jenis diatom epilitik hanya ditemukan di satu stasiun dan tidak ditemukan di stasiun yang lain sehingga nilai kepadatannya rendah.

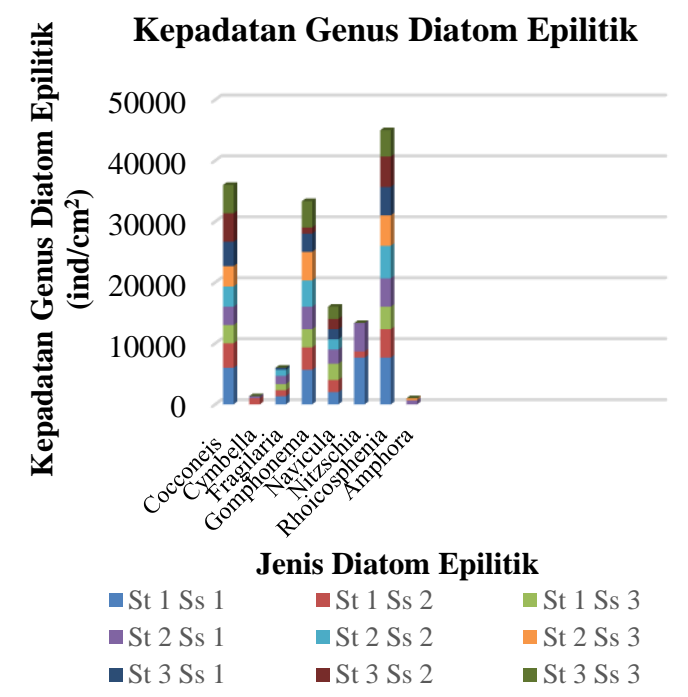

Gambar 3. Kepadatan setiap genus diatom di Coban Tarzan
Indeks keanekaragaman Shannon Wiener (H') diatom epilitik. Berdasarkan hasil pengamatan indeks keanekaragaman diatom epilitik di Coban Tarzan (Gambar 4), diperoleh keanekaragaman diatom yang berbeda di tiga stasiun. Secara keseluruhan, rata-rata nilai keanekaragaman pada kategori sedang $(1,52)$. Nilai keanekaragaman tertinggi adalah di stasiun satu dan semakin menurun sampai pada stasiun dua dan tiga. Kondisi ini dimungkinkan karena di stasiun tiga menjadi tempat akumulasi adanya gangguan dari aktivitas perkebunan sayuran dan pariwisata yang terjadi baik di stasiun dua dan tiga.

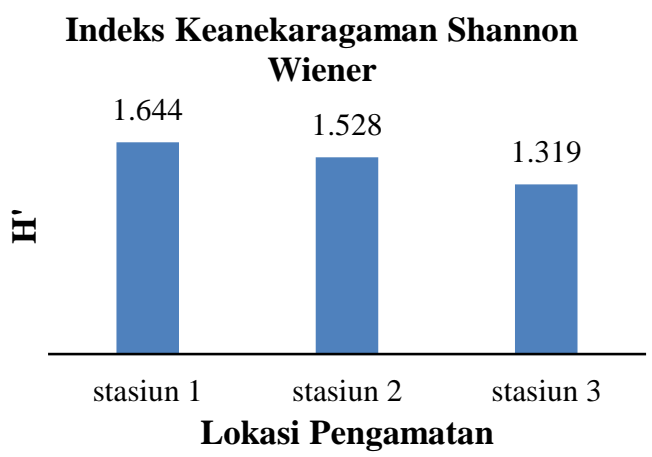

Gambar 4. Nilai indeks keanekaragaman diatom epilitik di Coban Tarzan

Nilai keanekaragaman diatom epilitik yang ditemukan di setiap stasiun pengamatan di aliran Coban Tarzan secara umum tergolong sedang. Kondisi ini dimungkinkan karena adanya gangguan terhadap ekosistem tersebut, seperti keberadaan perkebunan sayuran milik warga maupun aktivitas pariwisata di sekitarnya. Adanya aktivitas masyarakat di sekitar memungkinkan terjadinya gangguan terhadap ekosistem perairan di perairan sungai Coban Tarzan, sehingga dapat memengaruhi faktor lingkungan abiotik di perairan tersebut. Indeks keanekaragaman Shannon Wiener menunjukkan perbandingan antara variasi jumlah spesies dan jumlah individu tiap spesies. Suatu komunitas memiliki keanekaragaman tinggi apabila komunitas tersebut disusun oleh banyak jenis serta kelimpahan jenis yang merata [27]. Menurut [28], keanekaragaman jenis dipengaruhi oleh faktor lingkungan (abiotik), apabila terjadi gangguan di ekosistem seperti pencemaran, maka spesies yang toleran akan bertambah, sebaliknya spesies yang sensitif akan berkurang. Keanekaragaman organisme akuatik dapat digunakan sebagai bioindikator kualitas ekosistem. Tinggi rendahnya keanekaragaman organisme juga bisa digunakan sebagai indikator kualitas 
hayati. Aspek keanekaragaman bisa diketahui melalui jumlah spesies yang ditemukan. Nilai keanekaragaman juga ditentukan oleh jumlah takson yang berbeda serta keseragaman [29]. Semakin banyak jumlah spesies dengan nilai yang seimbang maka menunjukkan keanekaragaman yang semakin tinggi [28].

Indeks dominansi Simpson (C) diatom epilitik. Berdasarkan hasil pengamatan diatom epilitik di Coban Tarzan, nilai indeks dominansi Simpson setiap stasiun bervariasi seperti pada (Gambar 5). Secara keseluruhan, rata-rata nilai indeks dominansi menunjukkan tidak adanya spesies diatom epilitik yang mendominasi di perairan Coban Tarzan $(0,25)$. Nilai indeks dominansi paling rendah adalah di stasiun satu dan yang paling tinggi di stasiun tiga. Genus Cocconeis, Gomphonema, Navicula dan Rhoicosphenia menjadi contoh genus yang dapat ditemukan di semua lokasi stasiun pengamatan (Gambar 3).

Semakin kecil nilai indeks dominansi maka tidak ada dominansi spesies tertentu, sebaliknya semakin tinggi nilai indeks maka terdapat spesies yang mendominasi di suatu komunitas [22]. Secara keseluruhan, nilai indeks dominansi di ketiga stasiun pengamatan tergolong rendah. Kepadatan semua genus diatom epilitik yang ditemukan di aliran sungai Coban Tarzan hampir sama dan tidak ada jumlah individu genus yang mendominasi genus lainnya. Berdasarkan nilai indeks dominansi diatom epilitik di Coban Tarzan mengalami peningkatan mulai dari stasiun satu sampai dengan stasiun tiga. Kondisi ini memungkinkan nantinya akan terjadi dominansi spesies diatom epilitik di perairan tersebut. Selain itu, kondisi ini sesuai dengan nilai H' yang semakin menurun di stasiun tiga, bahwa telah terjadi akumulasi gangguan dari aktivitas manusia di stasiun tiga, sehingga memungkinkan adanya spesies yang dapat bertahan dari adanya gangguan tersebut dan menjadi spesies yang mendominasi di antara spesies lainnya.

\section{Indeks Dominansi Simpson}

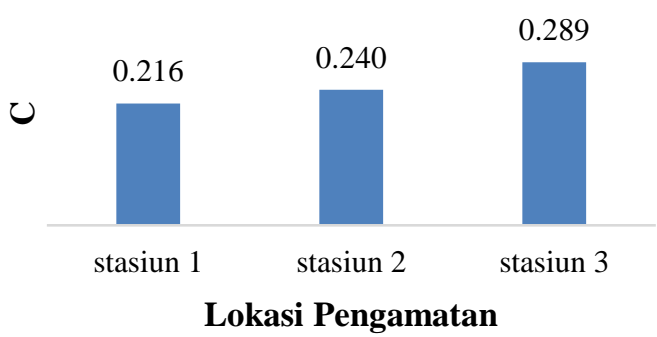

Gambar 5. Nilai indeks dominansi Simpson diatom epilitik di Coban Tarzan
Indeks Tropik Diatom (Trophic Diatom Index/TDI). Nilai TDI di semua stasiun pengamatan di Coban Tarzan menunjukkan nilai yang hampir sama (Gambar 6). Rata-rata nilai TDI di perairan sungai Coban Tarzan, yaitu 53,99. Nilai TDI terendah adalah di stasiun tiga, sedangkan stasiun dua merupakan stasiun dengan nilai TDI tertinggi. Semakin tinggi nilai TDI maka semakin tercemar suatu perairan [24]. Menurut [24], berdasarkan nilai TDI diatom epilitik yang terdapat di semua stasiun pengamatan di Coban Tarzan menunjukkan bahwa kategori nilai dan status pencemaran tidak jauh berbeda, sehingga aliran sungai di stasiun satu, dua dan tiga termasuk ke dalam kategori tercemar sedang dan status mesotrofik. Hasil perhitungan nilai TDI tersebut menunjukkan adanya kesesuaian dengan indeks diversitas yang juga sedang. Akan tetapi, jika disesuaikan dengan analisis indeks dominansi menunjukkan tidak ada spesies yang mendominasi, hanya saja terdapat beberapa genus diatom epilitik yang ditemukan dalam jumlah yang lebih banyak dibandingkan dengan genus lainnya. Selain itu, kondisi ini menunjukkan bahwa gangguan keberadaan aktivitas manusia sebenarnya telah terjadi secara merata di semua stasiun pengamatan di aliran sungai Coban Tarzan.

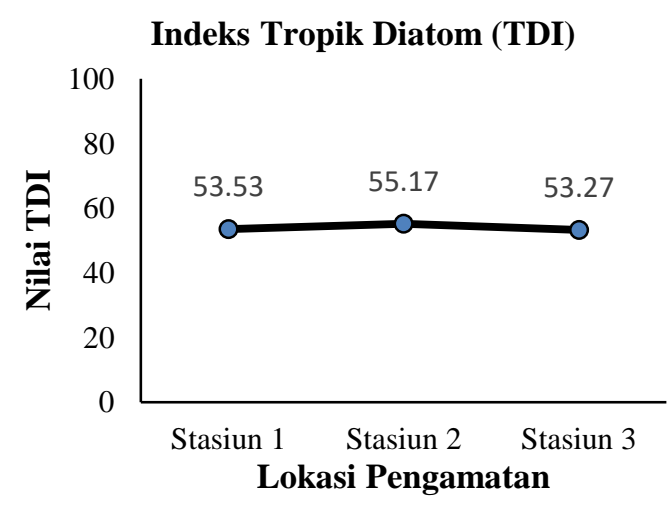

Gambar 6. Nilai Indeks Tropik Diatom epilitik di Coban Tarzan

\section{KESIMPULAN}

Kepadatan diatom epilitik yang ditemukan di aliran sungai Coban Tarzan selama penelitian adalah $152.669 \mathrm{ind} / \mathrm{cm}^{2}$, terdiri dari delapan genus (Amphora, Cocconeis, Cymbella, Fragilaria, Gomphonema, Navicula, Nitzschia dan Rhoicosphenia). Tingkat keanekaragaman diatom epilitik di tiga stasiun pengamatan secara keseluruhan memiliki nilai keanekaragaman pada kategori sedang $(1,52)$. Indeks dominansi Simpson menunjukkan tidak adanya spesies diatom epilitik yang 
mendominasi $(0,25)$. Tetapi ada beberapa genus diatom epilitik yang paling sering ditemukan diketiga stasiun pengamatan, di antaranya adalah genus Cocconeis, Gomphonema, Navicula dan Rhoicosphenia. Nilai TDI dari ketiga stasiun pengamatan menunjukkan perairan sungai Coban Tarzan tergolong dalam kategori sedang dan status mesotrofik.

Penelitian lanjutan dengan mengamati komposisi diatom epilitik pada Coban Tarzan yang dilakukan pada musim hujan menjadi salah satu saran untuk penelitian selanjutnya untuk semakin melengkapi data secara keseluruhan berdasarkan perbedaan musim dari aliran sungai di Coban Tarzan tersebut.

\section{UCAPAN TERIMA KASIH}

Penulis mengucapkan terima kasih kepada LP2M UIN Maulana Malik Ibrahim Malang yang telah memberikan bantuan penelitian lewat hibah bersaing dalam program SIMAPEL 2019. Ucapan terima kasih juga disampaikan kepada tim eksplorasi biodiversitas Coban Tarzan Kabupaten Malang di antaranya Berry Fakhry Hanifa, Muhammad Asmuni Hasyim, Mujahidin Ahmad, Yudha Setya Pranata, Haidar Nazaruddin Azwar, Rizky Mujahidin Ahmad, Dinda Tilanisari Farizki dan Lisana Sidqi Aliya.

\section{DAFTAR PUSTAKA}

[1] Styawan WMLD (2019) Studi keanekaragaman diatom epilitik dan hubungannya dengan kualitas perairan di Sub Das Brangkal, Kabupaten Mojokerto, Jawa Timur. Skripsi. UIN Maulana Malik Ibrahim Malang, Jurusan Biologi.

[2] Midaada, Avirista (2018). Sensasi Berpetulang di Wisata Alam Baru Air Terjun Tarzan di Malang. https://lifestyle. okezone.com/read/2018/09/09/406/19480 32/sensasi-berpetulang-di-wisata-alambaru-air-terjun-tarzan-di-malang. Diakses tanggal 7 Oktober 2019.

[3] Handayani ST, Suhato B, Marsoedi (2001) Penentuan status kualitas perairan Sungai Brantas Hulu dengan biomonitoring makrozoobentos: Tinjauan dari pencemaran bahan organik. BIOSAIN. 1(1). 30-38.

[4] Megawati N, Safitri E (2016) Komposisi alga epilitik di perairan Batang Kamumuan Kecamatan Sungai Limau Kabupaten
Padang Pariaman. Journal of Life Science. 2(1): 1-15.

[5] Siregar S, Mulyadi A, Hasibuan J (2008) Struktur komunitas diatom epilitik (Bacillariophyceae) pada lambung kapal di Perairan Dumai Provinsi Riau. Journal of Environmental Science. 2(2): 33-47.

[6] Friedrich G, Chapman D, Beim A (1992) The use of biological materials. dalam D. Chapman (Ed.). Water quality assessments a guide to use of biota, sediments and water in environmental monitoring. London. Chapman and Hall.

[7] Bellinger EG, David SC (2010) Freshwater algae identification and use as bioindicators. Manchester, Willey Blackwell.

[8] Ayuningsih MS, Boedi H, Pujiono WP (2014) Distribution and abundance of phytoplankton and chorophyll-a in the Sekumbu Bay Jepara Regency: Relationship with nitrate and phosphate content in water. Diponegoro Journal of Maquares 3(2): 138-147.

[9] Reavie RE, John PS (1998) Epilithic diatoms of the St. Lawrence River and their relationships to water quality. Can J Bot. 76: 251-257.

[10] Salomoni SE, Rocha O, Hermany G, Lobo E (2011) Alication of water quality biological indices using epilithic diatoms as bioindicators in the Gravatai River Brazil. Brazilian Journal Biology 71(4): 949-959.

[11] Lobo EA, Carlos EW, Luc F, Kazuhiro K, Saul B, Shigeki M (2010) Response of epilithic diatom communities to environmental gradients in subtropical temperate Brazilian rivers. Limnetica. 29(2): 323-340.

[12] Segura VG, Enrique A, Isabel I, Nora M (2012) Epilithic diatoms (Bacillariophyceae) as indicators of water quality in the upper Lerma River Mexico. Hidrobiologica. 22 (1): 16-27.

[13] Castilejo P, Susana C, Luiz P, Carla H, Ivonne C, Jose GS, Juan CN, Eduardo AL (2018) Response of epilithic diatom communities to environmental gradients along an Ecuadorian Andean River. Comptes Rendus Biologies. 341(4). 256263.

[14] Paul S, Bipul M, Manjushre M, Biswajit B, Sanoyaz S, Neera S (2016) Epilithic diatoms as biological water quality indcators a study in three geographical 
isolated hill streams in India. Journal of Enviromental Biology 37: 275-283.

[15] Hotzel G, Roger C (1999) A phytoplankton methods manual for Australian freshwaters. Canbera. LWRRDC.

[16] Tomas CR (1997) Identifying marine phytoplankton. Florida Marine Research Institute. Florida.

[17] Taylor JC, Harding W, Archibald C (2007) A methods manual for the collection, preparation and analysis of diatom samples. Water Research Comission. South Africa.

[18] Bellinger EG, David SC (2010) Freshwater algae identification and use as bioindicators. Manchester, Willey Blackwell.

[19] Taylor JC, Cocquyt C (2010) Diatom: methodologies and identification of the genera. Brussels, TBDC.

[20] American Public Health Association (2017) Standard methods for the examination of water and wastewater $23^{\text {nd }}$ edition. Washington. American Public Health Association.

[21] Fachrul FM (2008) Metode sampling bioekologi. Jakarta, Bumi Aksara.

[22] Odum EP (1993) Dasar-dasar ekologi. Yogyakarta, Gajah Mada University Press.

[23] Kelly MG, Whitton BA (1995) The Trophic Diatom Index: a new index for monitoring eutrophication in rivers. Journal of Applied Phycology 7: 433-444.

[24] Kelly MG (1998) Use of The Trophic Diatom Index to eutrophication in rivers monitor. Water Res. 32(1): 236-242.

[25] Srivastava P, Jyoti V, Sarika G, Ambrina S (2016) On the importance of diatoms as ecological indicators in river ecosystems. Indian Journal of Plant Sciences 5(1): 7086.

[26] Pasisingi N (2014) Diatom epilitik sebagai indikator kualitas air di bagian hulu Sungai Cileungsi, Bogor. Tesis. Institut Pertanian Bogor.

[27] Soegianto A (2010) Ekologi perairan tawar. Surabaya, Pusat Penerbitan dan Percetakan (AUP).

[28] Leksono AS (2007) Ekologi pendekatan deskriptif dan kuantitatif. Malang, Bayumedia Publishing.

[29] Wardhana W (2004) Metoda prakiraan dampak dan pengelolaannya pada komponen biota akuatik. Makalah Pelatihan Penyusunan AMDAL. PPSML UI. Jakarta. 